\title{
Papers
}

\section{The British pig health schemes: integrated systems for large-scale pig abattoir lesion monitoring}

\author{
M. J. Sanchez-Vazquez, W. D. Strachan, D. Armstrong, M. Nielen, G. J. Gunn
}

\begin{abstract}
Pig health schemes based on abattoir inspections provide an integrated system to optimise the postmortem detection and the reporting of pathological lesions. In Great Britain, two initiatives have been implemented by the pig industry: Wholesome Pigs Scotland (WPS) and the BPEX Pig Health Scheme (BPHS). These schemes record the presence of a range of pathological lesions detected by means of detailed inspection of the pluck and the skin of the slaughtered pigs. The lesions are those associated with a reduction in performance traits or are indicators of animal welfare problems. This paper aims to provide an overview of the objectives behind the BPHS and their activities, outlining similarities and differences between WPS and BPHS on five main operational topics: the lesions monitored, the administration of the schemes, flow of the information, inspection strategies and the major idiosyncratic characteristics of the schemes. These initiatives inform individual producers and their veterinarians of the occurrence of pathological conditions affecting their pig herds. Additionally, they offer the added value of providing nationwide disease monitoring information and have the potential to be a useful surveillance tool for emerging and enzootic conditions.
\end{abstract}

A coordinated industry-wide initiative to monitor the occurrence of gross pathology in pigs at slaughter was implemented in Great Britain with the development of two health schemes: Wholesome Pigs Scotland (WPS) started in 2003 and the BPEX Pig Health Scheme (BPHS) started in 2005. These schemes record the presence of various pathologies detected by means of detailed postmortem inspection (in the pluck and on the skin) of clinically healthy pigs submitted for slaughter and destined to enter the human food chain. The pathologies monitored are usually associated with a reduction in performance of those pigs presented with the lesions or are potential indicators of the presence of welfare problems in the herds. The health schemes provide feedback of results from the abattoir inspections to the participating producers and their herd veterinarians aiding an increase in their awareness of the occurrence of these diseases

Veterinary Record

M. J. Sanchez-Vazquez, DVM, MSc, MRCVS,

G. J. Gunn, BVMS, DipECVPH,

DipECBHM, MRCVS,

Scottish Agricultural College, Kings

Buildings, West Mains Road, Edinburgh, EH93JG, UK

W. D. Strachan, BSc, MA, VetMB,

PhD, MRCVS,

Boehringer Ingelheim Vetmedica,

Ellesfield Avenue, Bracknell, Berkshire, RG128YS, UK

D. Armstrong, MVB, MRCVS,

BPEX, Agriculture and Horticulture Development Board, Stoneleigh Park, Kenilworth, Warwickshire, CV8 2TL, UK in their herds. The Danish pig health scheme (Willeberg and others 1984) was an earlier attempt at establishing a structured operating system to standardise the collection of pig abattoir inspections data and to use them to improve the health of the herds of origin. In The Netherlands, an integrated quality control system to record and report the abattoir postmortem information was developed contemporaneously to the Danish scheme (Elbers and others 1992). Other European initiatives consisting of pig abattoir databanks have been utilised in Scandinavia and Northern Ireland (Willeberg and others 1984, Goodall and others 1993).

Abattoir inspections are a useful tool for pig health monitoring and have also been used as a data source for epidemiological studies. The presence of lung lesions in slaughter pigs (for example, pneumonia and pleurisy) has been used to investigate risk factors influencing respiratory conditions (Hurnik and others 1994, Stärk and others 1998, Cleveland-Nielsen and others 2002, Enøe and others 2002, Ostanello and others 2007, Fraile and others 2010, Sanchez-Vazquez and others 2010a, Meyns and others 2011). Milk spot liver postmortem findings have contributed to the investigation of the epidemiological and husbandry aspects of Ascaris suum (Bernardo and others 1990, Goodall and others 1991, Boes and others 2010, Sanchez-Vazquez and others 2010b).

Improving animal health surveillance and the identification of simple and reliable indicators of animal health are priorities in the current agenda of the EU on animal health strategy (European Commission 2007). The British pig health schemes, as unique initiatives of their kind, could be used as a model by other industries. Records from the health schemes are in the process of being incorporated into the national surveillance systems as part of the Rapid Analysis and Detection of Animal-related Risks system (DEFRA 2011). The systems provide high-quality data that offer opportunities for analysis in animal health and production research projects.

This paper describes the structure, working process and goals of the British pig health schemes initiatives and outlines the 
TABLE 1: Summary of the gross pathology description of respiratory conditions studied in pigs at slaughter and their most typical cause

\begin{tabular}{|c|c|c|c|c|}
\hline Lesion & Pathological lesion & Main causal agent & \multicolumn{2}{|l|}{ Scoring system } \\
\hline $\begin{array}{l}\text { Enzootic } \\
\text { pneumonia-like } \\
\text { lesions }\end{array}$ & $\begin{array}{l}\text { A red-tan-grey discolouration, collapse and } \\
\text { rubbery firmness affecting cranioventral } \\
\text { regions of the lungs in a lobular pattern }\end{array}$ & $\begin{array}{l}\text { Mycoplasma hyopneumoniae is the usual } \\
\text { causal infectious agent (Caswell and Williams } \\
\text { 2007) }\end{array}$ & \multicolumn{2}{|c|}{$\begin{array}{l}\text { Represent the approximate per cent of lung with consolidation. } \\
\text { Scale from } 0 \text { to } 55 \text { in five steps }\end{array}$} \\
\hline $\begin{array}{l}\text { Pleurisy } \\
\text { (or pleuritis) }\end{array}$ & Fibrous/fibrinous pleural adhesions & $\begin{array}{l}\text { Can be associated with Actinobacillus } \\
\text { pleuropneumoniae, Pasteurella species, } \\
\text { Mycoplasma hyorhinis, swine influenza and } \\
\text { Haemophilus parasuis (Enøe and others 2002) }\end{array}$ & \multicolumn{2}{|c|}{$\begin{array}{l}\text { Three categories. For WPS (and for BPHS until June 2008), the } \\
\text { three categories represent severity of the lesion with baseline } \\
\text { being absence. For BPHS (from July 2008), one for adhesions } \\
\text { between lung lobes only, two for adhesions involving the visceral } \\
\text { pleura and the parietal pleura and } 0 \text { for absence }\end{array}$} \\
\hline $\begin{array}{l}\text { Pleuropneumonia- } \\
\text { like lesion }\end{array}$ & $\begin{array}{l}\text { Focal areas of bronchopneumonia with } \\
\text { overlying pleurisy usually affecting the } \\
\text { middle or caudal lung lobes }\end{array}$ & $\begin{array}{l}\text { Often associated with A pleuropneumonioe } \\
\text { infection (Caswell and Williams 2007) }\end{array}$ & \multicolumn{2}{|c|}{ Binary: present or absent } \\
\hline \multicolumn{5}{|l|}{$\begin{array}{l}\text { Either acute or } \\
\text { chronic }\end{array}$} \\
\hline $\begin{array}{l}\text { Viral-like } \\
\text { pneumonia }\end{array}$ & $\begin{array}{l}\text { Lobular pattern with consolidation, rubbery } \\
\text { texture or congestion are typical of porcine } \\
\text { reproductive respiratory virus and porcine } \\
\text { circovirus type } 2 \text {. Atelectasis/collapsed areas } \\
\text { are observed with swine influenza }\end{array}$ & $\begin{array}{l}\text { Can be associated with porcine reproductive } \\
\text { respiratory virus, porcine circovirus type } 2 \\
\text { infection and swine influenza (Caswell and } \\
\text { Williams 2007) }\end{array}$ & \multicolumn{2}{|c|}{ Binary: present or absent } \\
\hline Abscess & Localised abscesses within lung & $\begin{array}{l}\text { Various secondary pathogens including } \\
\text { Arcanobacterium pyogenes (Huey 1996) }\end{array}$ & \multicolumn{2}{|c|}{ Binary: present or absent } \\
\hline Pyaemia & $\begin{array}{l}\text { Multiple small abscess detected in the lung } \\
\text { parenchyma }\end{array}$ & $\begin{array}{l}\text { Usually associated with a pyaemic spread of } \\
\text { infection from other focus. A pyogenes is a } \\
\text { frequent cause (Huey 1996) }\end{array}$ & \multicolumn{2}{|c|}{ Binary: present or absent } \\
\hline Snout score & $\begin{array}{l}\text { Atrophy of the ventral and dorsal nasal } \\
\text { tubinates, which is implicated by the } \\
\text { presence of more severe turbinate atrophy }\end{array}$ & $\begin{array}{l}\text { Toxigenic Posteurella multocida is the main } \\
\text { cause of progressive atrophic rhinitis (de Jong } \\
\text { 2006) }\end{array}$ & \multicolumn{2}{|c|}{$\begin{array}{l}\text { A sample of around } 20 \text { snouts per batch scored } 0-5 \text { according to } \\
\text { presence and severity of atrophy }\end{array}$} \\
\hline \multicolumn{5}{|c|}{ BPHS BPEX Pig Health Scheme, WPS Wholesome Pigs Scotland } \\
\hline Lesion & Pathological lesion & Main causal agent & & Scoring system \\
\hline Liver milk spots & $\begin{array}{l}\text { Whitish foci of fibrosis involving the liver } \\
\text { parenchyma }\end{array}$ & \multicolumn{2}{|c|}{$\begin{array}{l}\text { Ascaris suum larvae immobilised by the host's inflammatory reaction } \\
\text { (Stalker and Hayes 2007) }\end{array}$} & Binary: present or absent \\
\hline Hepatic scarring & $\begin{array}{l}\text { Mild fibrotic lesions affecting the capsule of } \\
\text { Glisson, with no liver parenchyma alteration }\end{array}$ & \multicolumn{2}{|c|}{ Possibly associated with healed Ascoris suum lesions } & Binary: present or absent \\
\hline $\begin{array}{l}\text { Papular } \\
\text { dermatitis }\end{array}$ & $\begin{array}{l}\text { Reddish papules/nodules found on ventrum, } \\
\text { neck and hams or widespread across the skin, } \\
\text { depending on the severity }\end{array}$ & \multicolumn{2}{|c|}{$\begin{array}{l}\text { This lesion is potentially associated with sarcoptic mange (Cargill and } \\
\text { others 1997) }\end{array}$} & $\begin{array}{l}\text { Four categories: accounting for severity and } \\
\text { distribution of the skin lesions, baseline } \\
\text { being absence }\end{array}$ \\
\hline Tail damage & Presence of old or recent tail lesions & \multirow{2}{*}{\multicolumn{2}{|c|}{$\begin{array}{l}\text { Typically associated with tail biting (Taylor and others 2010) } \\
\text { Associated with various bacteria such as Arcanobacterium } \\
\text { pyogenes and Escherichia coli. Serofibrinous lesions associated with } \\
\text { Haemophilus parasuis (Glässer's disease) and Streptococcus suis } \\
\text { (Reams and others 1994, Brown and others 2007) }\end{array}$}} & Binary: present or absent \\
\hline Peritonitis & Fibrous/fibrinous/fibrinopurulent lesions & & & Binary: present or absent \\
\hline Pericarditis & $\begin{array}{l}\text { Fibrous/fibrinous/fibrinopurulent adhesions } \\
\text { of the pericardium }\end{array}$ & \multicolumn{2}{|c|}{$\begin{array}{l}\text { Non-specific condition that could be associated with bacterial diseases, } \\
\text { for example, Glässer's diseases and pasteurellosis (Grant Maxie and } \\
\text { Robinson 2007) }\end{array}$} & Binary: present or absent \\
\hline
\end{tabular}

similarities and differences between WPS and BPHS. This paper is intended as a reference to inform current or potential stakeholders involved with such health schemes and to promote awareness of these initiatives.

\section{Materials and methods}

The combined experience of the authors, either involved in implementation of the health schemes or providing administrative and analytical support, along with an external view from an epidemiological perspective, has been used to review the internal protocols of WPS and $\mathrm{BPHS}$ and describe their characteristics. The main topics presented are the lesions monitored, the administration of the schemes, the flow of the information, the inspection strategies and the major unique characteristics of the schemes. Abattoir data for 2010 were accessed through WPS and BPHS to calculate descriptive figures (for example, number of pigs assessed, number of herds) that serve as indicators of the schemes' most recent activity.

\section{Results}

\section{Lesions}

The same 12 gross pathological lesions are reported by both health schemes: enzootic-pneumonia (EP)-like lesions, pleurisy, pleuropneumonic lesions, liver milk spots, hepatic scarring, papular dermatitis, tail damage, peritonitis, pericarditis, pyaemic lung lesions, lung abscesses and viral-like pneumonia. All the lesions are assessed and recorded independently, and multiple lesions can therefore be recorded for an individual pig. These 12 pathologies were chosen as they can be readily identified in the inspections of the pluck and by examining the skin and tail of the pig carcases. They are associated with reducing pig production efficiency and/or with animal welfare problems. The inspection of additional lesions in other organs/body parts (for example, nephritis, arthritis) would have been more time consuming and not feasible due to the abattoir line speed. Nasal turbinate atrophy is assessed in the WPS scheme when the condition is known to be a problem in the inspected herd.

The classification of the pathologies is per individual pig carcase and each pathology uses different scoring systems. EP-like lesion scores, pleurisy and papular dermatitis are scored in gradients that represent the severity or extent of the lesions. All the other lesions are scored in a binary form, recording just presence or absence of the lesions. A more detailed description is presented in Tables 1 and 2 .

\section{Administration of the health schemes}

The health schemes are implemented and managed by organisations funded via a levy collected for each slaughtered pig. WPS is administered with the support from Quality Meat Scotland (OMS 2011). $\mathrm{BPHS}$ is managed by the BPEX, a division of the agricultural and Horticultural Development Board (BPEX 2010). The administrators coordinate the stakeholders participating in the schemes, manage the budget, carry out knowledge transfer activities and appoint 


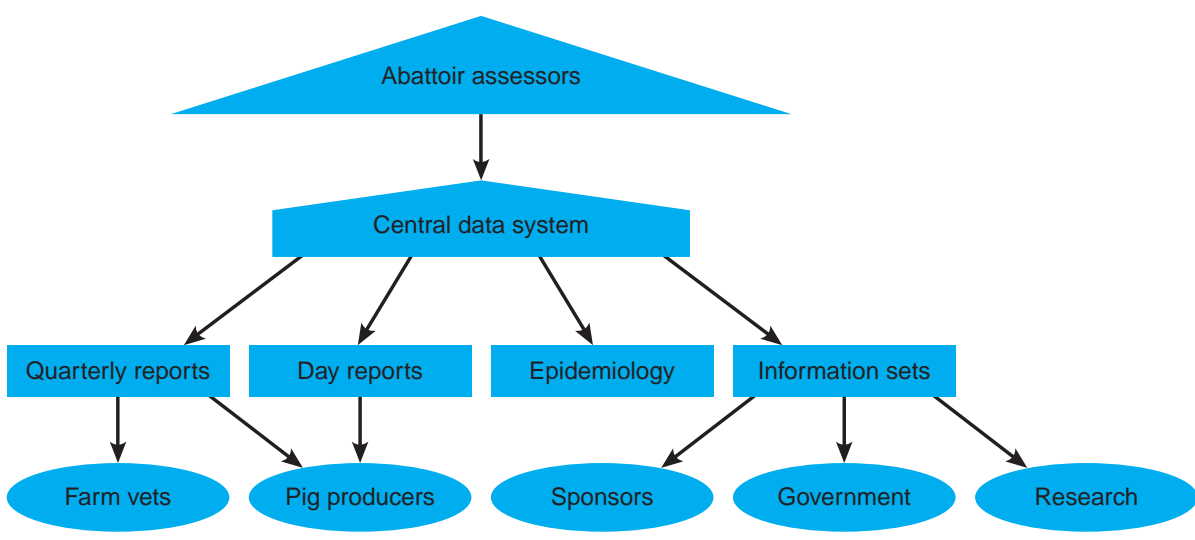

FIG 1: Diagram representing the flow of information in the pig health schemes, starting with the collection of electronic records of the gross pathology results in the abattoirs, to the summary reports sent to the producers and veterinary advisers

external services such as abattoir assessors, data processors and analysts. Steering group committees composed of managers, industry experts and other stakeholders oversee the health schemes and evaluate progress. In BPHS, six pharmaceutical companies are involved with sponsorship of the scheme and are represented in the steering committee.

Information flow from the assessments to the producers The scheme managers coordinate the veterinary assessment dates that are communicated to both producers and assessors at least three months in advance. The producers can then plan their pigs' submission to the abattoirs on the appropriate assessments dates. Batches of pigs, that is, a group of pigs from a single farm submitted to the abattoir on a particular date, are identified by their slapmarks. This is a unique official reference identifier for each holding consisting of an alphanumeric code tattooed on each shoulder. The health scheme assessments take place before the official inspections of offals and carcases. Disease information is electronically recorded directly on to handheld touchscreen computers at the time of the assessment on the slaughter line. After each assessment day, the assessors submit the electronically recorded information via e-mail to a central database. These data go via a validation process to ensure freedom from errors (for example, out of range scores, wrong dates). Fig 1 represents the information flow within the health schemes. A report summarising the findings for each batch of pigs submitted (including lesion prevalence data) is sent either by e-mail or by post to each producer and their veterinarian within 48 hours of the assessment (Fig 2 with the example for BPHS). Benchmarking reports for each unit, presenting the results in a graphical format and providing comparisons with average figures of all the members of the health schemes, are sent to producers and veterinarians on a quarterly basis (Fig 3 with the example for WPS). The information is held centrally and is used in routine descriptive epidemiological analyses to explore geographical and temporal distribution, the results of which are summarised in technical reports. These reports are made available internally and distributed to the health schemes' managers, assessors and sponsors. The data are also made available to research groups.

\section{Assessors and sampling strategies}

The scoring is carried out by pig specialists trained in this method of testing on the abattoir postmortem inspection line. WPS appoint the assessors directly. Originally, one veterinarian undertook the

\begin{tabular}{|c|c|c|c|c|c|c|c|c|c|c|c|c|c|c|}
\hline \multirow[t]{2}{*}{ Summary } & \multirow[b]{2}{*}{$\begin{array}{c}\text { EP } \\
\text { Ave Score }\end{array}$} & \multicolumn{5}{|c|}{ Lungs } & \multicolumn{2}{|c|}{ Liver } & \multicolumn{4}{|c|}{ Other } & \multirow{2}{*}{$\begin{array}{l}\text { Body } \\
\text { Tail } \\
\%\end{array}$} & \multirow{2}{*}{$\begin{array}{c}\text { Skin } \\
\begin{array}{c}\text { PD } \\
\text { Ave Score }\end{array}\end{array}$} \\
\hline & & $\begin{array}{c}\text { Virar } \\
\%\end{array}$ & $\begin{array}{c}\text { PP Chronic } \\
\%\end{array}$ & $\begin{array}{c}\text { PP Acute } \\
\%\end{array}$ & $\begin{array}{c}\text { Abscess } \\
\%\end{array}$ & $\begin{array}{l}\text { Pyaemia } \\
\%\end{array}$ & $\begin{array}{l}\text { MS } \\
\%\end{array}$ & $\begin{array}{c}\text { HS } \\
\%\end{array}$ & $\begin{array}{l}\text { Pleurisy } \\
\text { Loexiseds }\end{array}$ & $\begin{array}{c}\text { Pleurisy } \\
\text { Extensive } \%\end{array}$ & $\begin{array}{l}P C \\
\%\end{array}$ & $\begin{array}{l}P T \\
\text { \% }\end{array}$ & & \\
\hline & 1.95 & 0.00 & 0.00 & 0.00 & 0.00 & 0.00 & 200 & 0.00 & 8.00 & 4.00 & 6.00 & 2.00 & 0.00 & 0.04 \\
\hline Pigs Affected & 35 & 0 & 0 & 0 & 0 & 0 & 1 & 0 & 4 & 2 & 3 & 1 & 0 & 2 \\
\hline
\end{tabular}
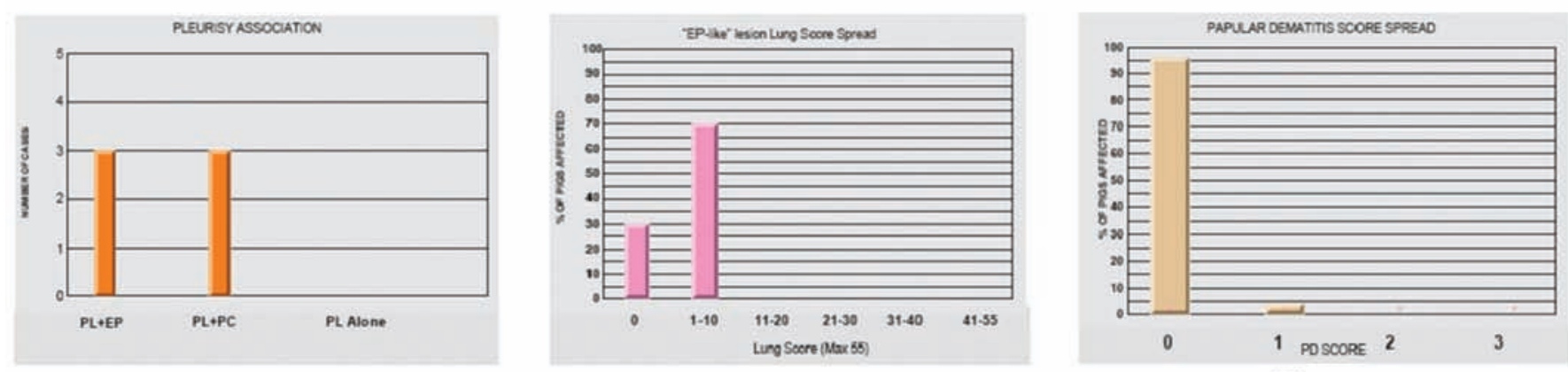

Comments: Slapmarks unclear

KEY

\begin{tabular}{|l|l|}
\hline EP & Enzootic Pneumonia \\
\hline "PP" & Pleuropneumonia-like \\
\hline "Viral" & Viral-type distribution \\
\hline MS & Milk Spot \\
\hline HS & Hepatic Scarring \\
\hline PC & Pericarditis \\
\hline PT & Peritonitis \\
\hline PL & Pleurisy \\
\hline PD & Papular Dermatitis \\
\hline Tail & Tail-bitten \\
\hline
\end{tabular}

(30806)

FIG 2: BPEX Pig Health Scheme producer batch report containing information on the prevalence of lesions in the batch of pigs assessed in the abattoir 


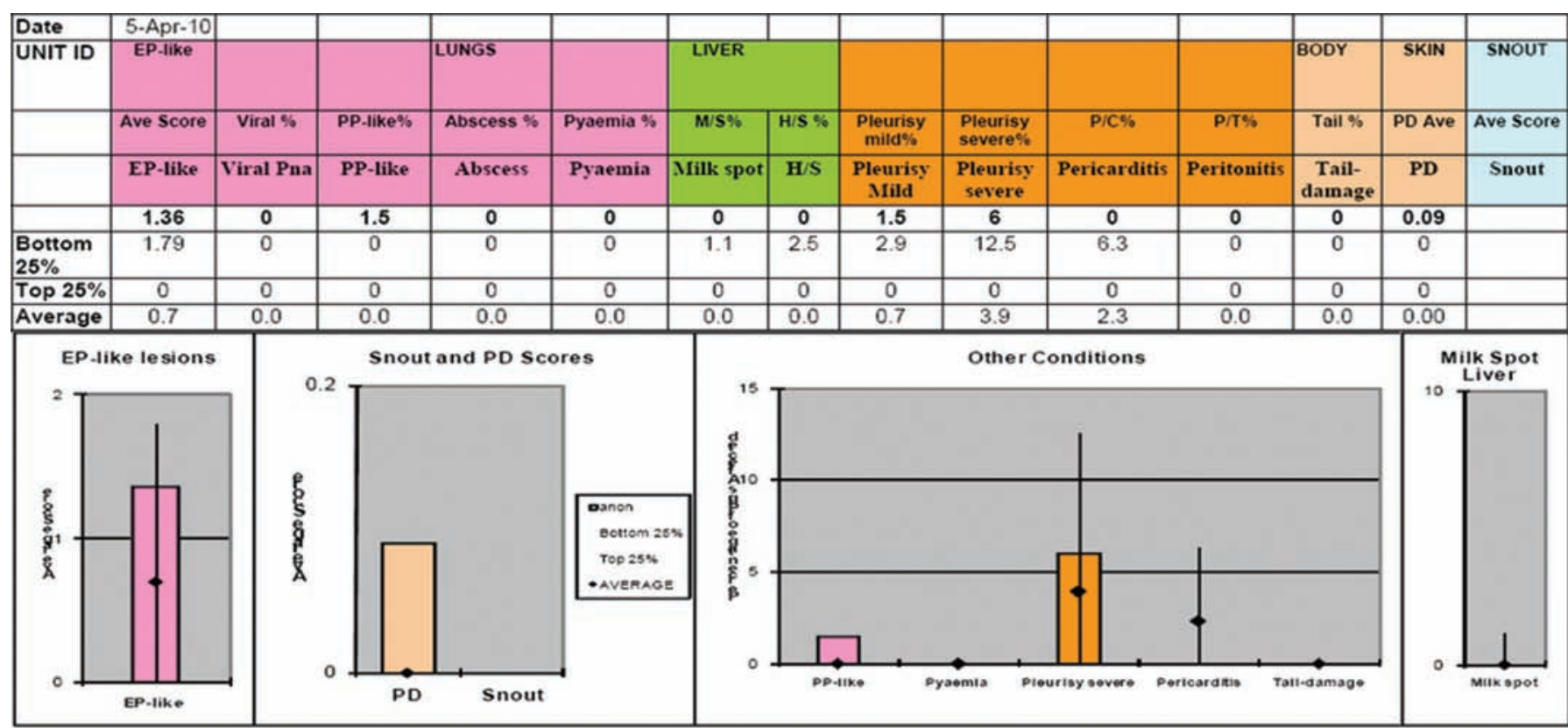

FIG 3: Wholesome Pigs Scotland quarterly producer report containing information on the prevalence of lesions in the batch assessed in the abattoir and the benchmark figures on the averages found for the scheme

assessments and a non-veterinarian pig specialist was used as a backup assessor. From 2010, two veterinarians carry out the inspections assisted by the non-veterinarian pig specialist. In BPHS, the assessors are appointed by an external contractor who is responsible for their recruitment and management. This scheme recruited only pig veterinarians as assessors. Fifty-five veterinary assessors in total have participated at some point in the scheme. Both schemes aim to record lesions from a representative sample from each batch of pigs by assessing every other pig on the slaughter line (due to fast line speeds), until the end of the batch in the case of WPS and up to a maximum of 50 pigs in the case of BPHS. All the large pig abattoirs in Britain where the plant operator gave the consent for the health schemes' inspections were recruited. WPS operates in three abattoirs in Scotland and BPHS operates in 14 abattoirs in England.

Both schemes carry out exercises to standardise the definition of the lesion across the inspectors. One veterinarian has been responsible for the training of all the other inspectors involved in the WPS assessments. The same veterinarian also participated in the training of BPHS assessors at the starting of the scheme. For WPS, once a year, all the inspectors undergo a refresher day where the same pigs are assessed by all the assessors in the abattoir line. For BPHS, three regional coordinators annually attend a standardisation day arranged by a veterinary adviser who is nominated by BPHS. Thereafter, the regional coordinators arrange and undertake regional standardisation days with all the other assessors. The regional coordinators will work on the line with two to three assessors scoring carcases simultaneously. This simultaneous scoring carried out in the abattoir line by WPS and BPHS aims to maintain the consistency in the scoring criteria across assessors by identifying and correcting potential misclassifications. Furthermore, BPHS aims to include at least two assessors per abattoir and each assessor should work in at least two different abattoirs, thereby minimising the clustering (at specific abattoir/herds) of potential operator bias.

\section{Unique characteristics of WPS and BPHS}

WPS was the first scheme implemented in Great Britain, and covers virtually all of the commercial finisher units located in Scotland. WPS carries out assessments on five days per quarter and aims to assess every producer every quarter. BPHS was developed after WPS following the same principles but implemented on a much larger scale. BPHS assesses and records the results from the inspections for all the batches of pigs slaughtered on the assessment days regardless of the membership status of the producers (that is, results for non-members are also recorded). All the assessments combined (members and non-members) would cover, with at least one assessment per year, 75 per cent of com- mercial finishing pigs farms in England and Wales (assuming a total of approximately 1400 commercial pig units [BPEX 2011]). Between one and four assessment days per month are carried out at each abattoir. BPHS aims to make at least one assessment per quarter for each member slapmark, as does WPS. Other characteristics of the health schemes are presented in Table 3 with comparison between WPS and BPHS. These descriptions use data for 2010 to provide indicative figures for the schemes.

\section{Discussion}

Health schemes have become one of the most important tools available to British farmers and their veterinarians for monitoring and tackling important health problems affecting efficiency of production and/ or animal welfare.

\section{Compliance of health schemes as a monitoring tool}

Conventionally, the use of abattoir records as a diagnostic tool has been limited by the lack of accuracy in the identification of the lesions. Enøe and others (2003) compared routine abattoir inspection (traditional) whose principal objective is to warrant food safety, with a more detailed inspection that focused on a number of pigs and specific organs. Both systems had adequate specificity and the sensitivity of detection of the conditions improved considerably when detailed inspection was carried out. These results could be extrapolated to the health schemes, in which detailed inspections are carried out and adequate sensitivity and specificity would be expected.

The median number of pigs assessed per batch was close to 50 in the case of WPS and is the target number established by BPHS. This number is adequate to detect conditions presenting with at least 5 per cent prevalence, assuming an average batch size of 200 pigs (Cannon and Roe 1982). While the prevalence estimated by the health schemes for conditions with high or low true prevalence is adequate, the level of confidence and/or precision would be diminished for those conditions whose true prevalence approaches 50 per cent (Cannon and Roe 1982). In many scenarios, the purpose of the abattoir monitoring would be assessing the impact of an intervention for which the ability of the schemes to detect the changes in prevalence would be more useful than just simply measuring the disease level at a point of time. Both schemes fail to achieve at least one assessment per herd slapmark in every quarter. The more assessments per slapmark, the more accurate the estimate of within-herd prevalence for the different conditions. This is particularly important for conditions such as milk spots and respiratory diseases that show seasonal patterns and for which occurrence appears to be clustered at batch level (Stark 2000, SanchezVazquez and others 2010a, b). In those scenarios, the results obtained 
TABLE 3: Comparison of the Wholesome Pigs Scotland (WPS) with BPEX Pig Health Scheme (BPHS) characteristics over 2010

\begin{tabular}{|c|c|c|}
\hline Lesion & WPS & BPHS \\
\hline Starting date & March 2003 & July 2005 \\
\hline Number of herds assessed & 157 & 516 members,520 non-members \\
\hline Number of inspections per year & 20,719 pigs, 405 batches & 180,539 pigs, 4185 batches \\
\hline Median and IQR for number of pigs assessed per batch & Median 47, IQR 24-75 & Median 50, IQR 40-50 \\
\hline Median and IQR for number of assessment per producer year & Median 2, IQR 1-4 & Median 3, IQR 2-5 \\
\hline Number of abattoir days" & 40 & 356 \\
\hline Number of abattoirs & 3 & 14 \\
\hline Number of assessors & 3 & 37 \\
\hline Representativeness & $\begin{array}{l}\text { Approximately } 100 \% \text { of the commercial units. } \\
\text { Membership is a requirement of QMS Farm Assurance } \\
\text { Scheme }\end{array}$ & Approximately $75 \%$ of the commercial units \\
\hline Funded by & Membership £50 per year. Levy funds & $\begin{array}{l}\text { Membership } £ 50 \text { per year.Levy funds, DEFRA (2005-2008) } \\
\text { and pharmaceutical companies }\end{array}$ \\
\hline Main services & $\begin{array}{l}\text { Benchmarked results on the batch prevalence detected } \\
\text { in the abattoirs to the producers and their veterinarians. } \\
\text { Individual reports are commented on by the veterinary } \\
\text { assessor }\end{array}$ & $\begin{array}{l}\text { Benchmarked results on the batch prevalence detected } \\
\text { in the abattoirs to the producers and their veterinarians. } \\
\text { Occasionally, individual reports are commented on by the } \\
\text { veterinary assessor }\end{array}$ \\
\hline Additional services & $\begin{array}{l}\text { Collection of blood samples for serological testing. } \\
\text { Collection of bile fluid samples for detection of mycotoxin } \\
\text { exposure. Ear swabs for sarcoptic mange inspection }\end{array}$ & $\begin{array}{l}\text { The possibility of collecting additional samples is offered by } \\
\text { the scheme but it has never been used }\end{array}$ \\
\hline Additional use of the data & Exploring temporal trends and geographical distribution & $\begin{array}{l}\text { Exploring temporal trends and geographical distribution. } \\
\text { Consistency across abattoirs }\end{array}$ \\
\hline Internal validation & $\begin{array}{l}\text { Scores by different assessors for the same pigs are } \\
\text { compared }\end{array}$ & $\begin{array}{l}\text { Regional standardiser covers different regions to maintain } \\
\text { the consistency of the assessments }\end{array}$ \\
\hline Programme cost per year & Approximately $£ 43,000$ & Approximately $£ 450,000$ \\
\hline
\end{tabular}

"Abattoir days: sum of total number of inspection days for all abattoirs in 2010

BPHS BPEX Pig Health Scheme, IQR Interquartile range, WPS Wholesome Pigs Scotland

from one assessment might not be representative of the over time prevalence for the herd since the lesion prevalence may vary between the different batches. The health schemes attempt to encourage the submission of multiple batches for assessment, but in many cases the producers fail to send the pigs on the specific dates when the assessments take place (for example, via simply missing dates, not having pigs ready for submission on the fixed dates or sending pigs to other non-participating abattoirs).

\section{Individual farm feedback}

The main objective of the pig health schemes is to provide feedback regarding the results on prevalence of selected conditions to the individual producers and their veterinarians. Apart from the day report with the individual herd prevalences, the producers receive a summary of the results every quarter benchmarked against the average for all the producers in the scheme. These reports not only increase the awareness of producers and their veterinarians' individual herd problems but also allow the comparison of herds within their own businesses and the comparison of their own herds with the industry as a whole. The benchmarked results seek to stimulate peer/industry pressure, which would help to motivate an intention to control disease, as was suggested by the socioecological model on farmers' attitude to control diseases proposed by Ellis-Iversen and others (2010). The producers and their veterinarians use the feedback from the health schemes to assess vaccine and worming interventions. In an internal survey of 55 producers and 42 veterinarians (carried out by BPEX in 2007), 60 and 80 per cent of them, respectively, reported taking actions on farms to address health issues as a result of the information contained in the $\mathrm{BPHS}$ reports (BPEX; unpublished observations). It is also likely that veterinarians whose practices have as clients both BPHS members and non-members use the results from members to review and implement health strategies across all clients and in this way, non-members benefit indirectly.

\section{Further uses of the health schemes data}

The collective use of the individual reports from the health schemes creates an opportunity to add value to these abattoir data. In a previous report, BPHS was considered to provide standardised results and reliable trends (Stärk and Nevel 2009). The health schemes make use of epidemiological tools to explore time trend and geographical distributions of the lesions. The data from the health schemes have also been of use for epidemiological studies to investigate the risk factors affect- ing some of these conditions (Sanchez-Vazquez and others 2010a, b) and their potential association with Salmonella infection (Smith and others 2011).

The combined results from both schemes provide a powerful tool for prevalence estimations on endemic diseases in the British finishing pig herd. The accuracy of the observed prevalence will depend on the representativeness of the batches assessed and of their herds. WPS monitors almost all the commercial farms in Scotland, since being a scheme member is a mandatory requirement of membership of the Quality Meat Scotland farm assurance scheme in that country. BPHS is estimated to assess 75 per cent of the English and Welsh commercial herds either as members or non-members. In England and Wales, BPHS membership is not obligatory for farm assurance schemes. In short, it could be considered that commercial producers are well represented by the health schemes' assessments and these provide a useful guide as to the prevalence of some important endemic diseases in finishing pigs.

\section{Limitations of the schemes}

The gross lesions assessed in the schemes persist for a limited time span depending on the speed of resolution of the particular pathology. For example, other work has shown that chronic pleurisy could only be detected for up to three months (Sorensen and others 2006) and milk spots only persisted for a month following infection (Stewart and Hoyt 2006). Lesions associated with early challenges in the life of the pigs will therefore not be detectable in the abattoir and cannot be monitored by the schemes. Furthermore, pigs that suffer a pathological condition on the farm and do not make it to the abattoir (that is, if they die) will not be represented in the batch assessments contributing to an underreporting in the prevalence of the condition. It is important that the results of the health inspections in the abattoir are carefully interpreted within the context of the current and historical information available on the specific batch of pigs and the farm in general.

The value of the health scheme reports may be more limited for all-in-all-out systems as by the time the results are available they are of little use for that particular group of pigs and the next group may come from a different source. In addition, the frequency of the assessments is not ideal for the rapid detection of exotic disease threats or emerging diseases in individual herds such as highlighting contagious diseases (for example, classical or African swine fever, highly pathogenic strains of swine influenza or porcine reproductive and respiratory syndrome virus). Hence, farm monitoring and syndromic surveillance are not replaced but are complemented by the health schemes. 
None of the lesions investigated is pathognomonic for a particular disease, and only a few (for example, EP-like lesions, milk spots and papular dermatitis) can be considered good proxies for specific pathogens (Cargill and others 1997, Sorensen and others 2006, Stalker and Hayes 2007, Meyns and others 2011). For the producers and their veterinarians, however, knowing the occurrence of the lesions is of value even if they have a complex aetiology, for example, pleurisy and abscesses (Huey 1996, Enøe and others 2002), as they are production-limiting conditions not easily detected when the animal is alive. Thus, producers and veterinarians can monitor their occurrence to keep it at what they consider to be an 'acceptable' prevalence level and/or implement husbandry practices and health strategies to reduce the occurrence of these conditions. In conclusion, health schemes are well-organised initiatives, with a complex logistical structure that allows coordination of inspections across different abattoirs and they contribute considerably to producer and veterinarian awareness of endemic diseases. Additionally, the health schemes contribute to the understanding of the national situation and progression of the endemic diseases. The future of the health schemes depends upon the availability of funding and the success in the expansion of BPHS across all the commercial finishing units.

\section{Acknowledgements}

The authors would like to acknowledge and thank all the people who make the health schemes possible on a daily basis: the assessors, the administrative and support staff and the managing organisations OMS and BPEX.

\section{References}

BERNARDO, T. M., DOHOO, I. R. \& OGILVIE, T. (1990) A critical assessment of abattoir surveillance as a screening test for swine ascariasis. Canadian Journal of Veterinary Research 54, 274-277

BOES, J., KANORA, A., HAVN, K. T., CHRISTIANSEN, S., VESTERGAARD NIELSEN, K., JACOBS, J. \& ALBAN, L. (2010) Effect of Ascaris suum infection on performance of fattening pigs. Veterinary Parasitology 172, 269-276

BPEX (2010) BPEX Annual Technical Report 2009-2010. Agriculture and Horticulture Development Board. ISBN 978-1-904437-45-1. pp. 5

BPEX (2011) Pig production guide. www.bpex.org.uk/Press/PigProductionGuide/overview. aspx. Accessed May 14, 2011

BROWN, C.C., BAKER, D.C., BARKER, I.K. (2007). Alimentary system. In Jubb Kennedy and Palmer's Pathology of Domestic Animals. Fifth Edition. Ed M Grant Maxie. Elsevier Saunders. pp. 1-295

CANNON, R. M. \& ROE, R. T. (1982) Livestock Disease Surveys: A Field Manual for Veterinarians. Bureau of Resource Science, Department of Primary Industry. Australian Government Publishing Service pp. 21

CARGILL, C. F., POINTON, A. M., DAVIES, P. R. \& GARCIA, R. (1997) Using slaugh ter inspections to evaluate sarcoptic mange infestation of finishing swine. Veterinary Parasitology 70, 191-200

CASWELL, J. L. \& WILLIAMS, K. J. (2007) Respiratory system. In Jubb, Kennedy and Palmer's Pathology of Domestic Animals. 5th edn. Ed M. G. Maxie. Elsevier Saunders. pp 591-593

CLEVELAND-NIELSEN, A., NIELSEN, E. O. \& ERSB ØLL, A. K. (2002) Chronic pleu ritis in Danish slaughter pig herds. Preventive Veterinary Medicine 55, 121-135

DE JONG, M. F., (2006) Progressive and nonprogressive atrophic rhinitis. In Diseases of Swine. 9th edn. Eds B. E. Straw, J. J. Zimmerman, S. D. Allaire, D. J. Taylor. Blackwell Publishing. pp 577-602

DEFRA (2011) Veterinary surveillance: rapid analysis \& detection of animal-related risks (RADAR). www.archive.defra.gov.uk/foodfarm/farmanimal/diseases/vetsurveillance/ radar/index.htm. Accessed May 14, 2011

ELBERS, A. R. W., TIELEN, M. J. M., SNIJDERS, J. M. A., CROMWIJK, W. A. J. \& HUNNEMAN, W. A. (1992) Epidemiological studies on lesions in finishing pigs in The Netherlands. I. prevalence, seasonality and interrelationship. Preventive Veterinary Medicine 14, 217-231

ELLIS-IVERSEN, J., COOK, A. J., WATSON, E., NIELEN, M., LARKIN, L., WOOLDRIDGE, M. \& HOGEVEEN, H. (2010) Perceptions, circumstances and moti- vators that influence implementation of zoonotic control programs on cattle farms. Preventive Veterinary Medicine 93, 276-285

ENØE, C., CHRISTENSEN, G., ANDERSEN, S. \& WILLEBERG, P. (2003) The need for built-in validation of surveillance data so that changes in diagnostic performance of post-mortem meat inspection can be detected. Preventive Veterinary Medicine 57, 117-125

ENØE, C., MOUSING, J., SCHIRMER, A. L. \& WILLEBERG, P. (2002) Infectious and rearing-system related risk factors for chronic pleuritis in slaughter pigs. Preventive Veterinary Medicine 54, 337-349

EUROPEAN COMMISSION (2007). A new Animal Health Strategy for the European Union (2007-2013) where 'Prevention is better than cure'. Office for Official Publications of the European Communities. pp 9

FRAILE, L., ALEGRE, A., LÓPEZ-JIMÉNEZ, R, NOFRARÍAS, M. \& SEGALÉS, J. (2010) Risk factors associated with pleuritis and cranio-ventral pulmonary consolidation in slaughter-aged pigs. Veterinary Journal 184, 326-333

GOODALL, E. A., MCLOUGHLIN, E. M., MENZIES, F. D. \& MCILROY, S. G. (1991) Time series analysis of the prevalence of Ascaris suum infections in pigs using abattoir condemnation data. Animal Production 53, 367-372

GOODALL, E. A., MENZIES, F. D., MCLOUGHLIN, E. M. \& MCILROY, S. G. (1993) Prevalence of pleurisy and pneumonia in pigs in Northern Ireland (1969-1989). Veterinary Record 132, 11-14

GRANT MAXIE, M. \& ROBINSON, W. F. (2007) Cardiovascular system. In Jubb, Kennedy and Palmer's Pathology of Domestic Animals. 5th edn. Ed M. G. Maxie Elsevier Saunders. pp 22-24

HUEY, R. J. (1996) Incidence, location and interrelationships between the sites of abscesses recorded in pigs at a bacon factory in Northern Ireland. Veterinary Record 138, 511-514 HURNIK, D., DOHOO, I. R., DONALD, A. \& ROBINSON, N. P. (1994) Factor analysis of swine farm management practices on Prince Edward Island. Preventive Veterinary Medicine 20, 135-146

MEYNS, T., VAN STEELANT, J., ROLLY, E., DEWULF, J., HAESEBROUCK, F. \& MAES, D. (2011) A cross-sectional study of risk factors associated with pulmonary lesions in pigs at slaughter. Veterinary Journal 187, 388-392

OSTANELLO, F., DOTTORI, M., GUSMARA, C., LEOTTI, G. \& SALA, V. (2007) Pneumonia disease assessment using a slaughterhouse lung-scoring method. Journal of Veterinary Medicine 54, 70-75

OMS (2011) Quality Meat Scotland. www.qmscotland.co.uk. Accessed May 14, 2011

REAMS, R. Y., GLICKMAN, L. T., HARRINGTON, D. D., THACKER, H. L. \& BOWERSOCK, T. L. (1994) Streptococcus suis infection in swine: a retrospective study of 256 cases. Part II. Clinical signs, gross and microscopic lesions and coexisting microorganisms. Journal of Veterinary Diagnostic Investigation 6, 326-334

SANCHEZ-VAZOUEZ, M. J., SMITH, R, GUNN, G. J., LEWIS, F., STRACHAN, D. W. \& EDWARDS, S. A. (2010a). The identification of risk factors for the presence of enzootic pneumonia-like lesions and pleurisy in slaughtered finishing pigs utilizing existing British pig industry data. Pig Journal 63, 25-33

SANCHEZ-VAZQUEZ, M. J., SMITH, R. P., KANG, S., LEWIS, F., NIELEN, M. GUNN, G. J. \& EDWARDS, S. A. (2010b) Identification of factors influencing the occurrence of milk spot livers in slaughtered pigs: a novel approach to understanding Ascaris suum epidemiology in British farmed pigs. Veterinary Parasitology 173, 271-279

SMITH, R. P., SANCHEZ-VAZOUEZ, M. J., COOK, A. J. \& EDWARDS, S. A. (2011) Abattoir-based study investigating the association between gross pathological lesions and serological tests for Salmonella infection in pigs. Veterinary Record 168, 240

SORENSEN, V., JORSAL, S. E. \& MOUSIN, J. (2006) Diseases of respiratory system. In Diseases of Swine. 9th edn. Eds B. E. Straw, J. J. Zimmerman, S. D. Allaire, D. J. Taylor. Blackwell Publishing. pp 149-177

STALKER, M. J. \& HAYES, M. A. T. (2007) Liver and biliary system. In Jubb, Kennedy and Palmer's Pathology of Domestic Animals. 5th edn. Ed M. G. Maxie. Elsevier Saunders. pp 298-358

STARK, K. D. C. (2000) Epidemiological investigation of the influence of environmental risk factors on respiratory diseases in swine-a literature review. Veterinary Journal 159, 37-56

STÄRK, K. D. \& NEVEL, A. (2009) Strengths, weaknesses, opportunities and threats of the pig health monitoring systems used in England. Veterinary Record 165, 461-465

STÄRK, K. D., PFEIFFER, D. U. \& MORRIS, R. S. (1998) Risk factors for respiratory diseases in New Zealand pig herds. New Zealand Veterinary Journal 46, 3-10

Stewart, T. B. \& Hoyt, P. G. (2006) Internal parasites. In Diseases of Swine. 9th edn. Eds B. E. Straw, J. J. Zimmerman, S. D. Allaire, D. J. Taylor. Blackwell Publishing. pp 901-914

TAYLOR, N. R., MAIN, D. C., MENDL, M. \& EDWARDS, S. A. (2010) Tail-biting: a new perspective. Veterinary Journal 186, 137-147

WILLEBERG, P., GERBOLA, M. A., PETERSEN, B. K. \& ANDERSEN, J. B. (1984) The Danish pig health scheme: nation-wide computer-based abattoir surveillance and follow-up at the herd level. Preventive Veterinary Medicine 3, 79-91 


\title{
veterinary The British pig health schemes: integrated systems for large-scale pig abattoir lesion monitoring
}

\author{
M. J. Sanchez-Vazquez, W. D. Strachan, D. Armstrong, et al.
}

Veterinary Record published online August 31, 2011

doi: $10.1136 / v r . d 4814$

Updated information and services can be found at:

http://veterinaryrecord.bmj.com/content/early/2011/08/31/vr.d4814.full.html

\section{These include:}

References This article cites 23 articles, 5 of which can be accessed free at: http://veterinaryrecord.bmj.com/content/early/2011/08/31/vr.d4814.full.html\#ref-list-1

$\mathbf{P}<\mathbf{P} \quad$ Published online August 31, 2011 in advance of the print journal.

Email alerting Receive free email alerts when new articles cite this article. Sign up in service the box at the top right corner of the online article.

Notes

Advance online articles have been peer reviewed, accepted for publication, edited and typeset, but have not not yet appeared in the paper journal. Advance online articles are citable and establish publication priority; they are indexed by PubMed from initial publication. Citations to Advance online articles must include the digital object identifier (DOIs) and date of initial publication.

To request permissions go to:

http://group.bmj.com/group/rights-licensing/permissions

To order reprints go to:

http://journals.bmj.com/cgi/reprintform

To subscribe to BMJ go to:

http://group.bmj.com/subscribe/ 